University of Nebraska - Lincoln

DigitalCommons@University of Nebraska - Lincoln

Faculty Publications: Department of

Entomology

Entomology, Department of

2018

\title{
Evaluation of Greenbug and Yellow Sugarcane Aphid Feeding Behavior on Resistant and Susceptible Switchgrass Cultivars
}

Kyle G. Koch

University of Nebraska-Lincoln, kkoch4@unl.edu

Teresa Donze-Reiner

West Chester University of Pennsylvania, tdonze@wcupa.edu

Lisa M. Baird

University of San Diego, Baird@sandiego.edu

Joe Louis

University of Nebraska-Lincoln, joelouis@unl.edu

Keenan L. Amundsen

University of Nebraska-Lincoln, kamundsen2@unl.edu

See next page for additional authors

Follow this and additional works at: https://digitalcommons.unl.edu/entomologyfacpub

Part of the Entomology Commons

Koch, Kyle G.; Donze-Reiner, Teresa; Baird, Lisa M.; Louis, Joe; Amundsen, Keenan L.; Sarath, Gautam; Bradshaw, Jeff; and Heng-Moss, Tiffany, "Evaluation of Greenbug and Yellow Sugarcane Aphid Feeding Behavior on Resistant and Susceptible Switchgrass Cultivars" (2018). Faculty Publications: Department of Entomology. 701.

https://digitalcommons.unl.edu/entomologyfacpub/701

This Article is brought to you for free and open access by the Entomology, Department of at DigitalCommons@University of Nebraska - Lincoln. It has been accepted for inclusion in Faculty Publications: Department of Entomology by an authorized administrator of DigitalCommons@University of Nebraska - Lincoln. 


\section{Authors}

Kyle G. Koch, Teresa Donze-Reiner, Lisa M. Baird, Joe Louis, Keenan L. Amundsen, Gautam Sarath, Jeff Bradshaw, and Tiffany Heng-Moss 


\title{
Evaluation of Greenbug and Yellow Sugarcane Aphid Feeding Behavior on Resistant and Susceptible Switchgrass Cultivars
}

\author{
Kyle G. Koch ${ }^{1} \cdot$ Teresa Donze-Reiner ${ }^{2} \cdot$ Lisa M. Baird ${ }^{3} \cdot$ Joe Louis $^{1} \cdot$ Keenan Amundsen ${ }^{4} \cdot$ Gautam Sarath $^{5}$. \\ Jeffrey D. Bradshaw ${ }^{1} \cdot$ Tiffany Heng-Moss ${ }^{1}$
}

Published online: 3 May 2018

(C) Springer Science+Business Media, LLC, part of Springer Nature 2018

\begin{abstract}
Switchgrass (Panicum virgatum L.) is an emerging biofuel crop that serves as host for aphids. To discern the effects of plant age and possible resistance mechanisms, the feeding behavior of greenbugs (Schizaphis graminum Rondani.) and the yellow sugarcane aphid (Sipha flava Forbes.) was monitored on three diverse switchgrasses by the electrical penetration graph (EPG) technique. Callose deposition and genes associated with callose metabolism were also analyzed to discern their association with plant resistance. There was a strong host effect on greenbugs feeding on lowland cultivar Kanlow at the V3 stage of development, as compared to the greenbug-susceptible upland cultivar Summer and plants derived from Kanlow $(\delta) \times$ Summer $(+)(\mathrm{K} \times \mathrm{S})$ crosses. These data confirmed that Kanlow at the V3 stage had antibiosis to greenbugs, which was absent in the Summer and $\mathrm{K} \times \mathrm{S}$ plants. In contrast, similar effects were not observed for yellow sugarcane aphids, excluding significant differences in the time to first probe on Kanlow plants at the V1 stage and reduction in time spent on pathway processes on Kanlow plants at the V3 stage. These data demonstrated that Kanlow plants may have multiple sources of resistance to the two aphids, and possibly some were phloem based. Microscopy of leaf sections stained with aniline blue for callose was suggestive of increased callose deposition in the sieve elements in Kanlow plants relative to Summer and $\mathrm{K} \times \mathrm{S}$ plants. RT-qPCR analysis of several genes associated with callose metabolism in infested plants was equivocal. Overall, these studies suggest the presence of multiple defense mechanisms against aphids in Kanlow plants, relative to Summer and $\mathrm{K} \times \mathrm{S}$ plants.
\end{abstract}

Keywords Switchgrass $\cdot$ Aphids $\cdot$ EPG $\cdot$ Feeding behavior $\cdot$ Callose $\cdot$ qPCR

\section{Introduction}

Electronic supplementary material The online version of this article (https://doi.org/10.1007/s12155-018-9914-3) contains supplementary material, which is available to authorized users.

Tiffany Heng-Moss

thengmoss2@unl.edu

1 Department of Entomology, University of Nebraska-Lincoln, Lincoln, NE 68583-0816, USA

2 Biology Department, West Chester University of Pennsylvania, West Chester, PA 19383, USA

3 Biology Department, University of San Diego, San Diego, CA 92110, USA

4 Department of Agronomy and Horticulture, University of Nebraska-Lincoln, Lincoln, NE 68583-0737, USA

5 Wheat, Sorghum, and Forage Research Unit, USDA-ARS, Lincoln, NE 68583-0917, USA
Switchgrass, Panicum virgatum L., is a perennial, polyploid warm-season grass native to tallgrass prairies of North America, east of the Rocky Mountains [1-3] and has been recognized to have excellent potential as a biomass crop [4-6]. Limited attention has been given to potential pest issues in this nascent sector; however, it is anticipated that important pests will emerge with increases in production. Indeed, studies to date indicate that switchgrass will not be immune to pests [7-11]. Accordingly, the long-term sustainability of switchgrass as a biomass crop will require efforts directed at improved biomass yields under a variety of biotic and abiotic stressors.

One particularly attractive method for controlling insect pests is plant resistance $[12,13]$. Differential resistance to two important cereal aphids, the greenbug, Schizaphis 
graminum (Rondani), and the yellow sugarcane aphid, Sipha flava (Forbes), has been demonstrated in tetraploid switchgrasses, and resistance varied with plant age for individual aphids $[7,14,15]$. Furthermore, using the electrical penetration graph (EPG) technique [16], it was possible to directly evaluate differential feeding behavior of the greenbug on upland cultivar Summer and lowland cultivar Kanlow plants [15]. These studies indicated a potential for phloem-based resistance in Kanlow plants, and limited resistance to aphid feeding in Summer plants, consistent with previous evaluations of host suitability in tetraploid switchgrasses [7].

The EPG technique allows the recording of signal waveforms corresponding to different probing activities as well as the position of the aphid stylet tips within the plant tissues [16], which can provide valuable information on host acceptance and resistance mechanisms at the plant tissue level [17-19]. Both greenbugs and yellow sugarcane aphids are phloem feeders, and phloem-based resistance in other plants has been attributed to sieve tube occlusion by callose [20-23].

Prior work indicated that the yellow sugarcane aphid was far more successful in colonizing switchgrass compared to the greenbug, suggesting a greater potential for the yellow sugarcane aphid to use switchgrass as a host $[7,9,14]$. These studies also indicated that switchgrass resistance/susceptibility to aphids may change with plant age $[9,14]$. In addition, Koch et al. (2014) indicated that a stabilized hybrid population of switchgrass initially derived by crossing Summer $\times$ Kanlow plants (hereafter referred to as $\mathrm{K} \times \mathrm{S}$ ) served as hosts for greenbugs and yellow sugarcane aphids, and likely lacked the phloem-based resistance observed in the Kanlow parents.

The current study was undertaken to specifically determine (a) if the age of switchgrass plants affected aphid feeding as monitored by EPG and (b) if callose deposition and the genes contributing to callose biosynthesis and/or degradation were differentially regulated in diverse tetraploid switchgrasses in response to aphid herbivory. The expectations were that (1) plant age would affect resistance to aphids, especially greenbugs in Kanlow plants, and would not affect greenbug feeding on Summer or $\mathrm{K} \times \mathrm{S}$ plants; (2) there would be limited resistance to yellow sugarcane aphid feeding on any switchgrass, since these aphids colonized all three switchgrasses; and (3) callose and genes associated with callose biosynthesis and degradation would be differentially regulated in these switchgrasses.

\section{Materials and Methods}

Overview of Experimental Setup This study evaluated the effect of switchgrass plant age on the feeding behaviors of two aphids, namely greenbug and the yellow sugarcane aphid. Previous studies had documented that plants at the V1 stage [24] of lowland cultivar Kanlow likely contained phloem- based resistance to greenbug feeding, whereas plants of the upland cultivar Summer did not. However, feeding behaviors of aphids on older plants of Kanlow, Summer, and $\mathrm{K} \times \mathrm{S}$ had not been evaluated [15]. No work has been reported on the feeding behaviors of the yellow sugarcane aphids on switchgrass.

The V1 stage of plant development (initial stage used for earlier EPG studies) was chosen to determine if callose was involved in response to aphid feeding, especially in Kanlow plants. Ectopic callose deposits in response to aphid feeding have been noted in other plant-aphid systems, and suggested to be an integral part of the plant defense response $[25,26]$. For experiments reported here, changes in leaf callose were determined using clip cages to limit the feeding area available for aphids, and maximize the potential for detection of this polymer. For qPCR, expression of select genes annotated in the switchgrass genome (version 1.1) as callose synthases or $\beta-1,3$ glucanases (callose degradation) was studied as a proxy for possible changes in callose deposition. These experiments required more plant tissues, and aphids were allowed to feed on V1 stage plants for 3 days to provide a reasonable timeframe to detect plant defense responses.

Plant Material Seedlings of two switchgrass cultivars 'Kanlow' and 'Summer,' and one experimental strain, $\mathrm{K} \times \mathrm{S}$ (HP1 C1 High Yield strain), developed by Dr. Kenneth Vogel, USDA-ARS (retired), Lincoln, NE, were raised from seeds in Cone-Tainers (Ray Leach SC10; Stuewe \& Sons, Inc., Tangent, OR) to the V1 or V3 stage [24] in a greenhouse under 400 -W high-intensity lamps with a 16 -h day and 8 -h night photoperiod at a temperature of $23^{\circ} \pm 4^{\circ} \mathrm{C}$.

Insect Colonies Colonies for Schizaphis graminum (greenbugs, biotype I) and Sipha flava (yellow sugarcane aphid) were obtained from Dr. John D. Burd, USDA-ARS in Stillwater, OK. Insect colonies were maintained on 'BCK60' sorghum plants as described earlier [14].

EPG Recording To assess the feeding behavior of $S$. graminum and $S$. flava, switchgrass plants were grown to the V3 developmental stage and selected for uniformity for all recordings. However, since no previous characterization of $S$. flava feeding behavior on switchgrass exists, a third study evaluated $S$. flava feeding behavior on plants in the V1 developmental stage. Before recordings, plants were transferred from the greenhouse to the laboratory $\left(23 \pm 5^{\circ} \mathrm{C}\right)$ and allowed to acclimate for approximately $24 \mathrm{~h}$.

A Giga-8 EPG model (EPG Systems, Wageningen, The Netherlands) with a $10^{9} \Omega$ resistance amplifier and an adjustable voltage was used to evaluate the feeding behavior of $S$. graminum and $S$. flava on switchgrass plants, essentially as described earlier [15]. Adult, apterous $S$. graminum and S. flava were held on a permissive host switchgrass $(\mathrm{K} \times \mathrm{S}$ and Summer, respectively) for $24 \mathrm{~h}$ prior to all recordings to 
precondition them to their host. Immediately before a recording, the aphids were placed in a petri dish and denied food for $1 \mathrm{~h}$ to increase the likelihood of feeding and to allow resheathing of their stylets [27]. After the starvation period, a gold wire was attached to the dorsum of an aphid, and placed on switchgrass plants for EPG measurements [15].

Generally, EPG waveforms are grouped into three broad behavioral phases: pathway phase, xylem, and phloem or sieve element phase [16, 28, 29]. Recordings were scored as previously defined by [15] using the following waveform patterns: $\mathrm{np}$ (non-probing), C (pathway phase; general probing in all plant tissues), pd (potential drops corresponding to intracellular punctures by stylet tips), E (salivation secretions into sieve elements and ingestion of phloem sap), and $\mathrm{G}$ (xylem ingestion).

EPG feeding behavior parameters were selected from the Sarria Excel Notebook [30]. The calculated parameters included the mean time from start of recording to first probe (elapsed time of placement of aphid on the plant to insertion of mouthparts); time from the first aphid probe to first sieve element phase and first sustained ( $\mathrm{E}>10 \mathrm{~min}$ ) sieve element phase; time to first sustained sieve element phase within a probe from the start of that probe; total number of potential drops, pathway phases, sieve element phases, sustained sieve element phases, xylem phases, and non-probing events; sum of duration of pathway phases, sieve element phases, xylem phases, nonprobing events, and first sieve element phase; mean duration of sieve element phases; and potential phloem ingestion index (PPII) and percent of aphids with sustained phloem ingestion.

Statistical Analysis EPG files were annotated by waveform, and the duration of each was calculated in Microsoft Excel Workbook. Data were combined, separated by switchgrass population and aphid number (replication) for each experiment, and converted to comma-separated values (CSV). The combined data were checked for errors using a beta-program designed for SAS software [31]. Once errors in waveform labeling were corrected, the data were tested for significance by using analysis of variance (ANOVA), implemented in PROC GLIMMIX. When appropriate, means were separated using Fisher's least significant difference (LSD) test $(\alpha=0.05)$. Normality was assessed for all parameters using graphical analysis of the residuals and a Shapiro-Wilk test [32]. Parameters for waveform durations ranged widely and generally did not meet the assumptions of normality. Goodness-of-fit tests indicated that fitted lognormal or gamma distributions were good models for the distribution of duration parameters not meeting the assumptions of normality; therefore, data were analyzed with the appropriate probability distribution for each parameter.

Callose Histochemistry. Ten adult S. graminum or S. flava were confined within a custom aphid clip cage, constructed of two heavy-duty double-stick foam tape squares (25.4 by 25.4 by $1.5 \mathrm{~mm}$; 3M Co., St. Paul, MN) and foam sheets.
Aphids were confined for $3 \mathrm{~h}, 6 \mathrm{~h}, 12 \mathrm{~h}$, or 3 days on the newest, fully developed leaf of V1 switchgrasses. Control plants were similarly caged, but without aphids. At the end of the infestation period, leaf material within the clip cage was excised and immediately placed into a solution of ethanol/ acetic acid $(3: 1 v / v)$. Samples were placed into a shaker and incubated at room temperature for at least $24 \mathrm{~h}$, changing the solution several times, until all samples were cleared of pigments. Tissues were dehydrated in ethanol, embedded in paraffin, and sectioned to obtain $20-\mu \mathrm{m}$ sections (Veterinary Diagnostics Center, University of Nebraska-Lincoln). After removal of paraffin, slides were then stained with $0.01 \%(w /$ v) aniline blue in $0.01 \mathrm{M} \mathrm{K}_{3} \mathrm{PO}_{4}$ for $10 \mathrm{~min}$, rinsed briefly in water, and observed using an Olympus BX-51 fluorescence microscope. Whereas earlier EPG measurements had suggested phloem-based resistance in Kanlow plants relative to Summer, and $\mathrm{K} \times \mathrm{S}$ plants, especially at the $\mathrm{V} 1$ stage, it was not evident if these Summer and $\mathrm{K} \times \mathrm{S}$ plants also produced callose in response to aphid herbivory, albeit at lower levels.

Quantitative Real-Time PCR Based on a previously published RNA-Seq dataset [11], the expression of three callose synthaserelated and six $\beta$-1,3-glucanase-related genes was investigated using quantitative real-time PCR (RT-qPCR) (Table 1). Switchgrass plants were grown to the V1 developmental stage as described earlier before being infested with ten adult apterous greenbugs or yellow sugarcane aphids. The plants were arranged in a complete randomized design consisting of three treatments (greenbug-infested, yellow sugarcane aphidinfested, and control). Infested and control plants were individually caged with tubular plastic cages as described earlier. Plants were harvested and flash frozen 3 days after infestation, to mirror the last time point taken for callose measurements.

Four individual plants (biological replicates) were processed from each treatment. Total RNA was extracted from approximately $75 \mathrm{mg}$ of frozen plant tissue as previously described [33, 34] using the TRIzol reagent (Invitrogen, Carlsbad, CA), and purified using the RNeasy® MinElute ${ }^{\mathrm{TM}}$ Cleanup Kit (Qiagen, Valencia, CA) according to the manufacturer's protocols. The integrity of RNA bands was confirmed via agarose gel electrophoresis, while quantification and purity of RNA were determined with a spectrophotometer (NanoDrop 1000, Wilmington, DE). First strand cDNA was synthesized using $2.5 \mu \mathrm{g}$ of total RNA with the ThermoScript ${ }^{\mathrm{TM}}$ RT-PCR system (Life Technologies, Carlsbad, CA) utilizing manufacturer-suggested protocols.

RT-qPCR was performed on a 7500 Fast Real-time PCR (Applied Biosystems, Foster City, CA) using Bio-Rad SsoAdvanced ${ }^{\mathrm{TM}}$ SYBR ${ }^{\circledR}$ Green (Bio-Rad Laboratories, Hercules, CA) following the manufacturer's protocol $\left(95^{\circ} \mathrm{C}\right.$ for $30 \mathrm{~s}$, followed by 40 cycles of $95^{\circ} \mathrm{C}$ for $5 \mathrm{~s}$ and $60{ }^{\circ} \mathrm{C}$ for 30 s). Glyceraldehyde-3-phosphate dehydrogenase (GAPDH) was included as the endogenous control gene. Gene ids and 
Table 1 Gene ID, gene description, and gene primers (FWD and REV) used for RT-qPCR of callose-related genes in switchgrass plants

\begin{tabular}{llll}
\hline Gene ID & Gene description & FWD primer & REV primer \\
\hline Pavir.Ab00948 & Callose synthase 8-related & 5'-AAGAAGTGAT GCCCGAGAGA-3' & 5'-CAGTCCCACT GAGAAGAGCC-3' \\
Pavir.Bb02930 & 1,3 Beta-glucosidase precursor & 5'-GCATTGCCTC TGCTCTTCTT-3' & 5'-GCGTCGTAGA TCCTGACCAT-3' \\
Pavir.Ca01420 & Glycosyl hydrolase family 1 (glucanase) & 5'-TGGTCCAGGC TTATTCCAAG-3' & 5'-CAGGATCTGA GGGAAATCCA-3' \\
Pavir.Db00045 & 1,3-Beta-glucan synthase component & 5'-GCACTGGCTA CTGGAAGGAG-3' & 5'-TCTCCAGACC GATTTCCATC-3' \\
Pavir.Eb03869 & Glycosyl hydrolases family 17 (glucanase) & 5'-ACATTTGCAG CCATCCCTAC-3' & 5'-GTAGATGCGC ATGAGGTTGA-3' \\
Pavir.Ga01393 & Glycosyl hydrolase family 1 (glucanase) & 5'-AGGCAGATGT AGTGTTGGGG-3' & 5'-GGGAGAAGGG AAGAAACCAG-3' \\
Pavir.Gb01472 & Beta-glucanase & 5'-ACCGAGTGAA ACACTGGACC-3' & 5'-ACTTCCCTTT TGTACGGCCT-3' \\
Pavir.Ia04498 & Callose synthase 3 & 5'-GCTACTTCAC AACCGTGGGT-3' & 5'-GCCTTCCCAA ATCCTCTTTC-3' \\
Pavir.J17017 & 1,3 Beta-glucosidase precursor & 5'-CGTCAACAAC GTCATCAACC-3' & 5'-GTGGTGGAAG TCGAAATCGT-3' \\
\hline
\end{tabular}

primers used for amplification are given in Table 1. Calculations of $\Delta \Delta \mathrm{CT}$ were performed with the values of cycle threshold (CT) for each primer and GAPDH as an endogenous control, according to Schmittgen, Livak [35], and the statistical significance of CT values was determined through generalized mixed model analysis (PROC GLIMMIX, SAS Institute 2008).

\section{Results}

\section{EPG}

Yellow sugarcane aphid V1 Analysis of variance determined that switchgrass effects were not significant for duration of major waveform patterns for yellow sugarcane aphids feeding on V1 switchgrasses (Online Resource 1). A significant difference was detected for the time from the start of the experiment to first probe due to a delay in probing on Summer $\left(12.5 \pm 6.8 \mathrm{~min} ; t_{26}=2.14 ; P=0.0422\right)$ compared to Kanlow $(1.3 \pm 0.9 \mathrm{~min})$. Additionally, the duration of the first sieve element phase was significantly lower on $\mathrm{K} \times \mathrm{S}(24.4 \pm$
$6.9 \mathrm{~min})$ relative to both Summer $\left(127.7 \pm 50.0 \mathrm{~min} ; t_{57}=\right.$ $3.60 ; P=0.0007)$ and Kanlow $\left(66.8 \pm 25.3 \mathrm{~min} ; t_{57}=2.19\right.$; $P=0.0327$ ) (Table 2). No significant differences were found for mean number of stylet activities, potential phloem ingestion index (PPII), or the percentage of aphids with sustained ingestion (Online Resource 2).

Yellow sugarcane aphid V3 Analysis of variance detected significant differences for duration of two waveform patterns, specifically total duration of pathway and xylem phases, for yellow sugarcane aphids feeding on V3 developmental switchgrasses (Fig. 1). Yellow sugarcane aphids feeding on $\mathrm{K} \times \mathrm{S}(258.7 \pm 32.4 \mathrm{~min})$ spent significantly more time in pathway than aphids on Kanlow $\left(187.5 \pm 33.9 \mathrm{~min} ; t_{57}=2.01 ; P=\right.$ 0.0490). Similarly, yellow sugarcane aphids also spent significantly more time in the xylem phase on $\mathrm{K} \times \mathrm{S}(115.4 \pm$ $11.6 \mathrm{~min})$ relative to Summer plants $\left(75.6 \pm 12.3 \mathrm{~min} ; t_{53}=\right.$ $2.11 ; P=0.0394)$. However, analysis of variance did not detect significant differences for the total duration sieve element phases or non-probing. Likewise, there were no significant differences among any of the phloem-based parameters or for other aphid feeding parameters related to detailed time
Table 2 Comparison of EPG parameters (mean \pm SEM) for time and duration of pattern segments for $15 \mathrm{~h}$ of yellow sugarcane aphid feeding on switchgrass populations (V1 stage)

\begin{tabular}{|c|c|c|c|}
\hline \multirow[t]{2}{*}{ Feeding variable } & \multicolumn{3}{|l|}{ Mean $\pm \mathrm{SEM}^{\mathrm{a}}$} \\
\hline & Summer & $\mathrm{K} \times \mathrm{S}$ & Kanlow \\
\hline Time to 1 st probe ${ }^{b}$ & $12.5 \pm 6.8 \mathrm{a}$ & $6.5 \pm 3.1 \mathrm{ab}$ & $1.3 \pm 0.9 b$ \\
\hline Time to $1 \mathrm{st} \mathrm{SEP}^{\mathrm{c}}$ & $103.1 \pm 27.3 \mathrm{a}$ & $85.2 \pm 17.2 \mathrm{a}$ & $138.0 \pm 34.6 \mathrm{a}$ \\
\hline Time to 1 st sustained SEP ${ }^{\mathrm{d}}$ & $235.4 \pm 77.6 \mathrm{a}$ & $142.4 \pm 37.4 \mathrm{a}$ & $255.1 \pm 54.8 \mathrm{a}$ \\
\hline Mean duration of SEP & $123.6 \pm 34.7 \mathrm{a}$ & $3.0 \pm 9.7 \mathrm{a}$ & $117.5 \pm 28.8 \mathrm{a}$ \\
\hline Duration of 1 st SEP & $127.7 \pm 50.0 \mathrm{a}$ & $24.4 \pm 6.9 b$ & $66.8 \pm 25.3 \mathrm{a}$ \\
\hline \multicolumn{4}{|l|}{ SEP sieve element phase } \\
\hline \multicolumn{4}{|c|}{$\begin{array}{l}\text { a Treatment means within the same row followed by the same letter indicate no significant differences }(P \leq 0.05) \text {, } \\
\text { LSD test }\end{array}$} \\
\hline \multicolumn{4}{|c|}{${ }^{\mathrm{b}}$ Time and duration calculated in minutes } \\
\hline \multicolumn{4}{|l|}{${ }^{\mathrm{c}}$ Sieve element phase } \\
\hline Sustained sieve element $\mathrm{p}$ & & & \\
\hline
\end{tabular}




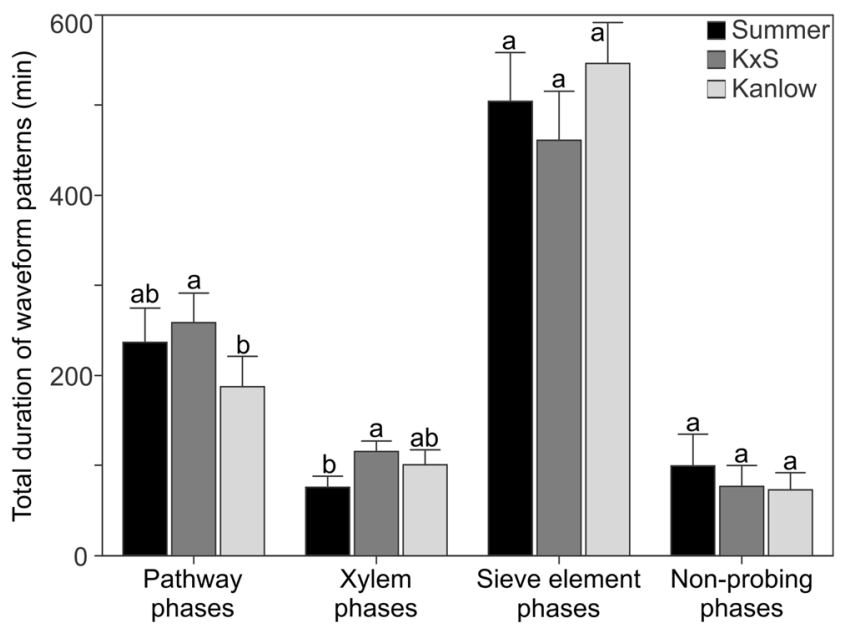

Fig. 1 Comparison of EPG parameters (mean \pm SEM) for duration of pathway, xylem, phloem, and non-probing phases for $15 \mathrm{~h}$ of yellow sugarcane aphid feeding on three switchgrass populations (V3 stage). Bars with the same letter within a column are not significantly different $(P>0.05)$, LSD test

and duration of pattern segments and for numerical parameters of aphid stylet activities among any of the switchgrasses (Online Resource 3, 4).

Greenbug V3 Analysis of variance detected significant differences for greenbug probing parameters linked to stylet pathway activities and sieve element phases on $\mathrm{V} 3$ switchgrasses. Greenbugs feeding on V3 switchgrass spent significantly less time in phloem sieve elements on Kanlow $(66.8 \pm 30.5 \mathrm{~min})$ compared to $\mathrm{K} \times \mathrm{S}\left(239.4 \pm 44.7 \mathrm{~min} ; t_{57}=2.20 ; P=0.0321\right)$ (Fig. 2). While the duration of sieve element phases was higher on Summer $(179.6 \pm 45.6 \mathrm{~min})$ relative to Kanlow, as well, this difference was not statistically significant. However, the duration for the first sieve element phase was significantly less on $\mathrm{K} \times \mathrm{S}(4.3 \pm 1.2 \mathrm{~min})$ relative to both Summer $(77.8 \pm$

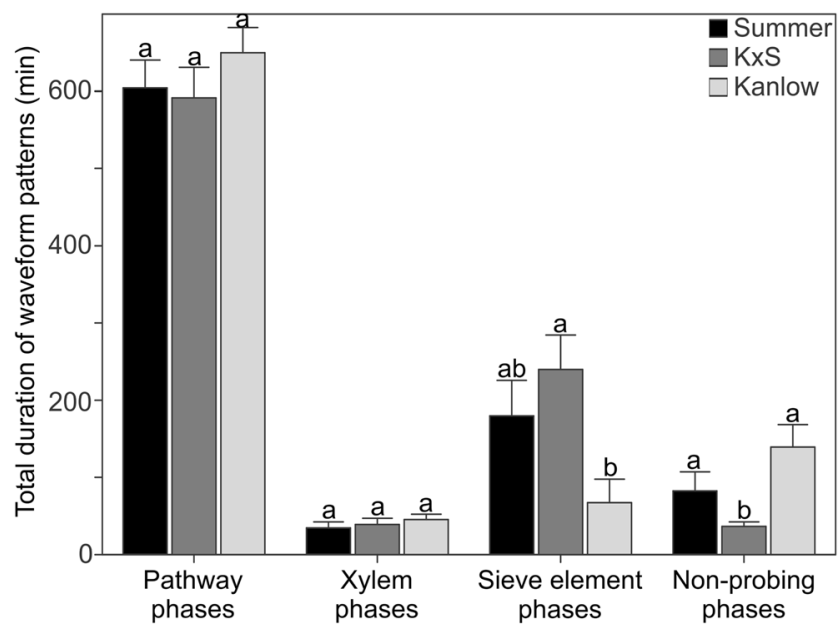

Fig. 2 Comparison of EPG parameters (mean \pm SEM) for duration of pathway, xylem, phloem, and non-probing phases for $15 \mathrm{~h}$ of greenbug feeding on three switchgrass populations (V1 stage). Bars with the same letter within a column are not significantly different $(P>0.05)$, LSD test $\left.42.2 \mathrm{~min} ; t_{48}=5.42 ; P<0.0001\right)$ and Kanlow $(49.7 \pm$ $32.5 \mathrm{~min} ; t_{48}=3.86 ; P=0.0003$ ) (Table 3 ). Significant differences were also discovered in the time that it took greenbugs to achieve a sustained sieve element phase from the first probe (Table 3) with aphids taking less time on $\mathrm{K} \times \mathrm{S}(557.7 \pm$ $80.6 \mathrm{~min})$ in comparison to Kanlow $\left(830.6 \pm 55.2 \mathrm{~min} ; t_{23}=\right.$ 2.34; $P=0.0281$ ). Parameters for the mean number of sieve element phases and mean number of sustained sieve element phases also had significant differences (Table 4). Greenbugs had significantly fewer sieve element events on Kanlow (1.2 $\pm 0.4)$, relative to Summer $\left(6.4 \pm 1.1 ; t_{48}=4.46 ; P<0.0001\right)$ and $\mathrm{K} \times \mathrm{S}\left(5.7 \pm 0.7 ; t_{48}=4.00 ; P=0.0002\right)$. Likewise, the aphids had fewer sustained sieve element events on Kanlow $(0.3 \pm 0.1)$ when compared to both Summer $\left(0.8 \pm 0.2 ; t_{40}=\right.$ $4.10 ; P=0.0002)$ and $\mathrm{K} \times \mathrm{S}\left(1.2 \pm 0.2 ; t_{40}=4.96 ; P<0.0001\right)$. Accordingly, the percent of greenbugs with sustained sieve element ingestion was significantly lower for Kanlow (25) relative to Summer $\left(60 ; t_{57}=2.18 ; P=0.0332\right)$ and $\mathrm{K} \times \mathrm{S}(85$; $\left.t_{57}=3.49 ; P=0.0009\right)$ (Table 4).

Several significant differences were documented for nonphloem-based parameters as well. The total duration of time spent in non-probing (Fig. 2) was significantly lower for greenbugs on $\mathrm{K} \times \mathrm{S}(36.0 \pm 5.7 \mathrm{~min})$ compared to Summer $\left(82.1 \pm 24.8 \mathrm{~min} ; t_{57}=2.28 ; P=0.0263\right)$ as well as Kanlow $\left(139.0 \pm 29.2 \mathrm{~min} ; t_{57}=3.30 ; P=0.0017\right)$. In relation, the number of non-probing events (Table 4) was significantly greater for greenbugs on Kanlow $(17.6 \pm 1.5)$ relative to $\mathrm{K} \times \mathrm{S}\left(12.8 \pm 1.6 ; t_{57}=2.48 ; P=0.0160\right)$. Finally, significantly more potential drops (Table 4 ) were recorded for aphids probing on Kanlow $(262.7 \pm 13.5)$ in comparison to $\mathrm{K} \times \mathrm{S}(220.9 \pm$ $\left.17.6 ; t_{57}=2.17 ; P=0.0341\right)$.

\section{Callose}

Histochemistry There were no obvious differences in callose deposition, regardless of treatment for 3-, 6-, or 12-h evaluations. Likewise, no conspicuous differences were observed between treatments at 3 days for $\mathrm{K} \times \mathrm{S}$ or Summer (Fig. 3). However, 3 days after infestation, callose deposits appeared to be relatively abundant on sieve plates and the cell walls of vascular tissue for Kanlow plants infested with greenbugs, relative to uninfested controls as well as the susceptible $\mathrm{K} \times \mathrm{S}$ (Figs. 3 and 4). Few callose deposits were also observed on Kanlow infested with yellow sugarcane aphids at 3 days. Similarly, results of staining leaves from V3 stage plants were equivocal and did not reveal any consistent evidence for callose deposition.

Quantitative real-time PCR Four $\beta$-1,3-glucosidase transcripts were significantly upregulated in switchgrasses fed on by greenbugs, relative to the uninfested controls (Fig. 5a). Specifically, the $\beta$-1,3-glucanases, Pavir.Gb01472 and Pavir.J17017, were significantly upregulated in Summer 
Table 3 Comparison of EPG parameters (mean $\pm \mathrm{SEM}$ ) for time and duration of pattern segments for $15 \mathrm{~h}$ of greenbug feeding on switchgrass populations (V3 stage)

\begin{tabular}{|c|c|c|c|}
\hline \multirow[t]{2}{*}{ Feeding variable } & \multicolumn{3}{|l|}{ Mean $\pm \operatorname{SEM}^{\mathrm{a}}$} \\
\hline & Summer & $\mathrm{K} \times \mathrm{S}$ & Kanlow \\
\hline Time to 1 st probe $^{\mathrm{b}}$ & $2.4 \pm 1.0 \mathrm{a}$ & $1.4 \pm 0.8 \mathrm{a}$ & $2.7 \pm 2.0 \mathrm{a}$ \\
\hline Time to $1 \mathrm{st} \mathrm{SEP}^{\mathrm{c}}$ & $264.9 \pm 45.2 \mathrm{a}$ & $302.8 \pm 58.6 \mathrm{a}$ & $464.3 \pm 94.7 \mathrm{a}$ \\
\hline Time to 1 st sustained $\mathrm{SEP}^{\mathrm{d}}$ & $666.0 \pm 79.6 \mathrm{ab}$ & $557.7 \pm 80.6 b$ & $830.6 \pm 55.2 a$ \\
\hline Mean duration of SEP & $82.6 \pm 35.3 a$ & $61.8 \pm 15.4 \mathrm{a}$ & $72.9 \pm 32.8 \mathrm{a}$ \\
\hline Duration of 1st SEP & $77.8 \pm 42.2 \mathrm{a}$ & $4.3 \pm 1.2 b$ & $49.7 \pm 32.5 \mathrm{a}$ \\
\hline
\end{tabular}

plants, while Pavir.Eb03869 was significantly upregulated in both Summer and $\mathrm{K} \times \mathrm{S}$, compared to their respective controls. Additionally, a fourth $\beta$-1,3-glucanase, Pavir.Ca01420, was also upregulated in $\mathrm{K} \times \mathrm{S}$ plants after 3 days of greenbug infestation. Differential expression between greenbug-infested and control plants was not significantly different for any of the callose synthase-related genes.

In response to yellow sugarcane aphid feeding, two callose-related genes were significantly upregulated (Fig. 5b). In Summer plants, the callose synthase 8-related gene, Pavir.Ab00948, was significantly upregulated after yellow sugarcane aphid feeding, compared to uninfested plants. The $\beta$-1,3-glucanase, Pavir.Eb03869, was the only gene to be significantly upregulated in yellow sugarcane aphid-infested $\mathrm{K} \times \mathrm{S}$ plants. Differential expression between aphid-infested and control plants was not significantly different for any of the genes examined in Kanlow plants with respect to either aphid species (Online Resource 5 and 6).

\section{Discussion}

Among tetraploid switchgrass evaluated for susceptibility to aphids, the lowland cultivar Kanlow was largely resistant to greenbug herbivory and moderately resistant to yellow sugarcane aphids. In contrast, the upland cultivar Summer and $\mathrm{K} \times \mathrm{S}$ plants were susceptible to injury by both aphids [14]. Plant resistance to aphids can occur via a number of mechanisms [36], and some ascribed to phloem-based mechanisms could involve callose $[25,37,38]$. The EPG technique is an effective way to document the feeding behavior of aphids. Waveforms documented through EPG are associated with different aspects of aphid probing and feeding on plant tissues. Based on the occurrence and duration of these waveforms, it is possible to infer plant resistance mechanisms [16, 39]. Previously, Koch et al. [15] documented significant differences in greenbug feeding behavior on the V1-stage Kanlow plants relative to Summer and $\mathrm{K} \times \mathrm{S}$ plants, and data suggested the presence
Table 4 Comparison of EPG parameters (mean \pm SEM) for stylet activities for $15 \mathrm{~h}$ of greenbug feeding on switchgrass populations (V3 stage)

\begin{tabular}{|c|c|c|c|}
\hline \multirow[t]{2}{*}{ Feeding variable } & \multicolumn{3}{|l|}{ Mean $\pm \mathrm{SEM}^{\mathrm{a}}$} \\
\hline & Summer & $\mathrm{K} \times \mathrm{S}$ & Kanlow \\
\hline Potential drops & $223.5 \pm 12.1 \mathrm{ab}$ & $220.9 \pm 17.6 b$ & $262.7 \pm 13.5 \mathrm{a}$ \\
\hline Pathway phases & $22.9 \pm 2.2 \mathrm{a}$ & $20.7 \pm 2.0 \mathrm{a}$ & $22.0 \pm 1.3 \mathrm{a}$ \\
\hline Xylem phases & $2.7 \pm 0.5 \mathrm{a}$ & $2.4 \pm 0.4 \mathrm{a}$ & $3.1 \pm 0.5 \mathrm{a}$ \\
\hline $\mathrm{SEP}^{\mathrm{b}}$ events & $6.4 \pm 1.1 \mathrm{a}$ & $5.7 \pm 0.7 \mathrm{a}$ & $1.2 \pm 0.4 \mathrm{~b}$ \\
\hline Sustained $\mathrm{SEP}^{\mathrm{c}}$ events & $0.8 \pm 0.2 \mathrm{a}$ & $1.2 \pm 0.2 \mathrm{a}$ & $0.3 \pm 0.1 b$ \\
\hline $\mathrm{NP}^{\mathrm{d}}$ events & $13.7 \pm 1.7 \mathrm{ab}$ & $12.8 \pm 1.6 \mathrm{~b}$ & $17.6 \pm 1.5 \mathrm{a}$ \\
\hline Potential phloem ingestion index (PPII) & $28.5 \pm 7.4 \mathrm{a}$ & $40.6 \pm 6.8 \mathrm{a}$ & $42.4 \pm 13.1 \mathrm{a}$ \\
\hline$\%$ of aphids showing sustained SEP $(E>10 \mathrm{~min})$ & $60(12 / 20) a$ & $85(17 / 20) a$ & $25(5 / 20) \mathrm{b}$ \\
\hline
\end{tabular}



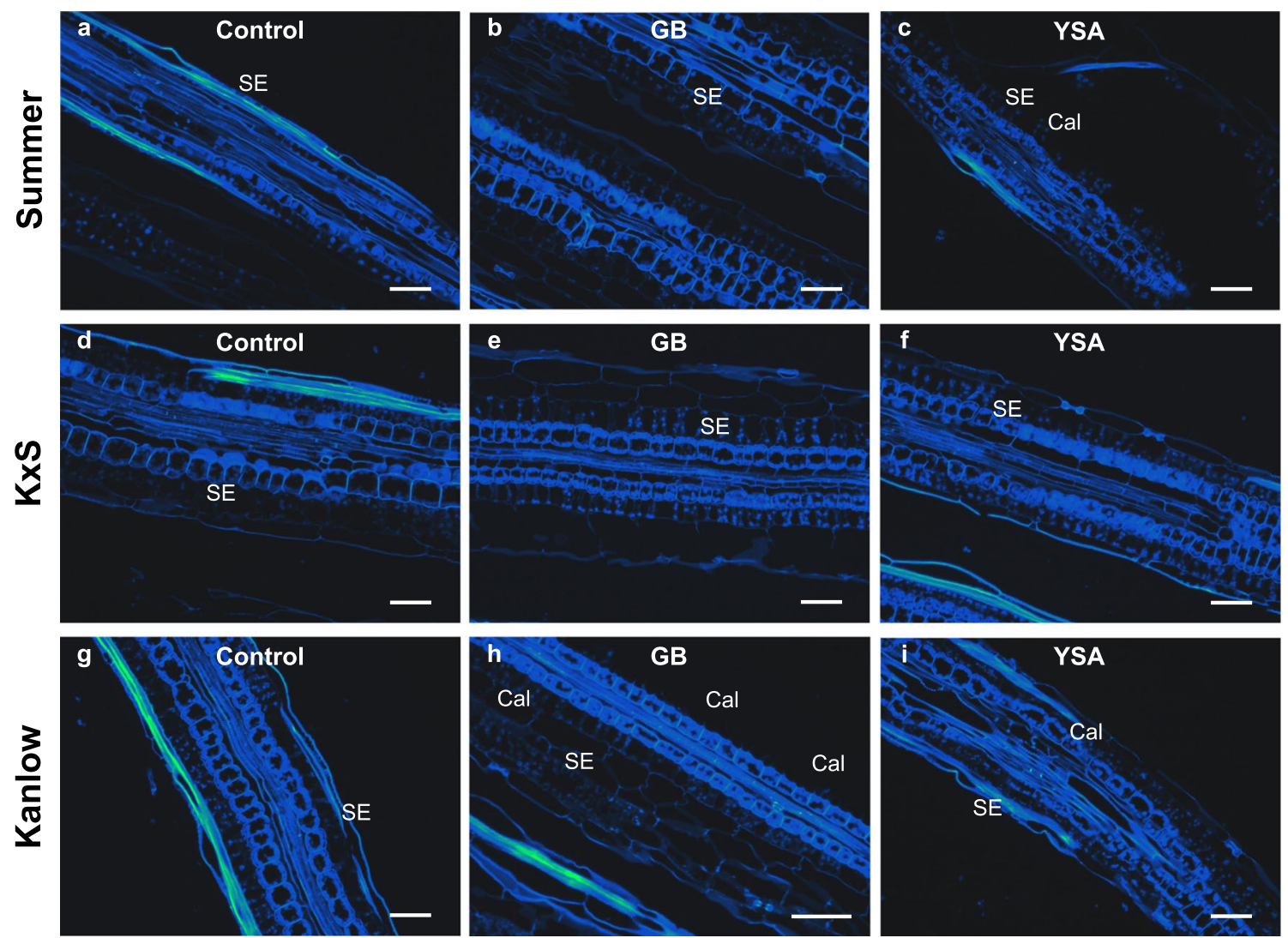

Fig. 3 Fluorescence micrographs of longitudinal leaf sections for switchgrass plants. a-c Summer, $\mathbf{d}-\mathbf{f} \mathrm{K} \times \mathrm{S}$, and $\mathbf{g}-\mathbf{i}$ Kanlow. Induced callose deposition (arrows) on the sieve plates (bluish-green fluorescence)

of phloem-based resistance to greenbugs in Kanlow plants, but not Summer or $\mathrm{K} \times \mathrm{S}$ plants.

Studies with switchgrass have indicated that plants become a less suitable host for several cereal aphids with increased age [9, 14]. Interestingly, results presented here indicate that greenbug phloem ingestion is reduced on more mature (V3) switchgrasses, compared to a previous report of greenbug feeding on V1 switchgrass. Koch et al. [15] demonstrated that in 15-h recordings, greenbugs spent more than one third of their time in sieve element phases on Summer and $\mathrm{K} \times \mathrm{S}$ plants (304.2 and $339.9 \mathrm{~min}$, respectively). However, in this study, similar 15-h recordings on V3 switchgrass demonstrated that sieve element phases were reduced for greenbugs on Summer and $\mathrm{K} \times \mathrm{S}$ to 179.6 and $239.4 \mathrm{~min}$, respectively. While this appears to support previous reports suggesting a compromise in successful aphid colonization on later developmental stages of switchgrass, it remains unclear if a reduction in phloem access contributes to the abated performance of greenbugs or is a consequence of other factors.

The lack of significant differences for yellow sugarcane aphid feeding behavior on both developmental stages of switchgrass is curious, given the greater levels of resistance in Kanlow, relative to Summer and $\mathrm{K} \times \mathrm{S}$ [7, 14]. Indeed, yellow sugarcane aphids appear to have little issue reaching sieve elements and sustaining ingestion on the resistant Kanlow. This would seem to suggest that resistance in Kanlow is truly due to antibiosis, with no apparent contribution from antixenotic factors. Moreover, it also indicates that resistance is likely not a result of physical barriers during probing (e.g., callose or p-protein plugging of sieve pores). However, many other factors could be negatively affecting aphid fitness or demographics. For example, resistance could be conferred by the presence of plant secondary metabolites with toxicity to aphids (e.g., DIMBOA) [21, 40], growth inhibitors (e.g., quercetin) [41], or changes in plant metabolism to limit nutrient availability [12]. The benzoxazinoid, DIMBOA, confers toxicity to several cereal aphids, including greenbugs [42], and is an important element of Rhopalosiphum maidis resistance in maize [12, 21]. In maize, DIMBOA-Glc is activated by glucosidases to DIMBOA upon insect feeding, which then activates insect-deterrent metabolites [21, 43]. Crucially, benzoxazinoids are relatively ubiquitous in Gramineae and some evidence suggests that DIMBOA may be present in switchgrass [44].

Callose has been previously linked to resistance to piercing-sucking insects [20-23]. Kempema et al. [23] reported that CALS1 mutant Arabidopsis plants upregulated callose synthase $(C A L S 1)$ gene transcription in response to silverleaf whitefly, Bemisia tabaci (Gennadius), infestation. Moreover, the CALS1 mutants also displayed significant callose deposition around whitefly feeding sites, indicating callose 

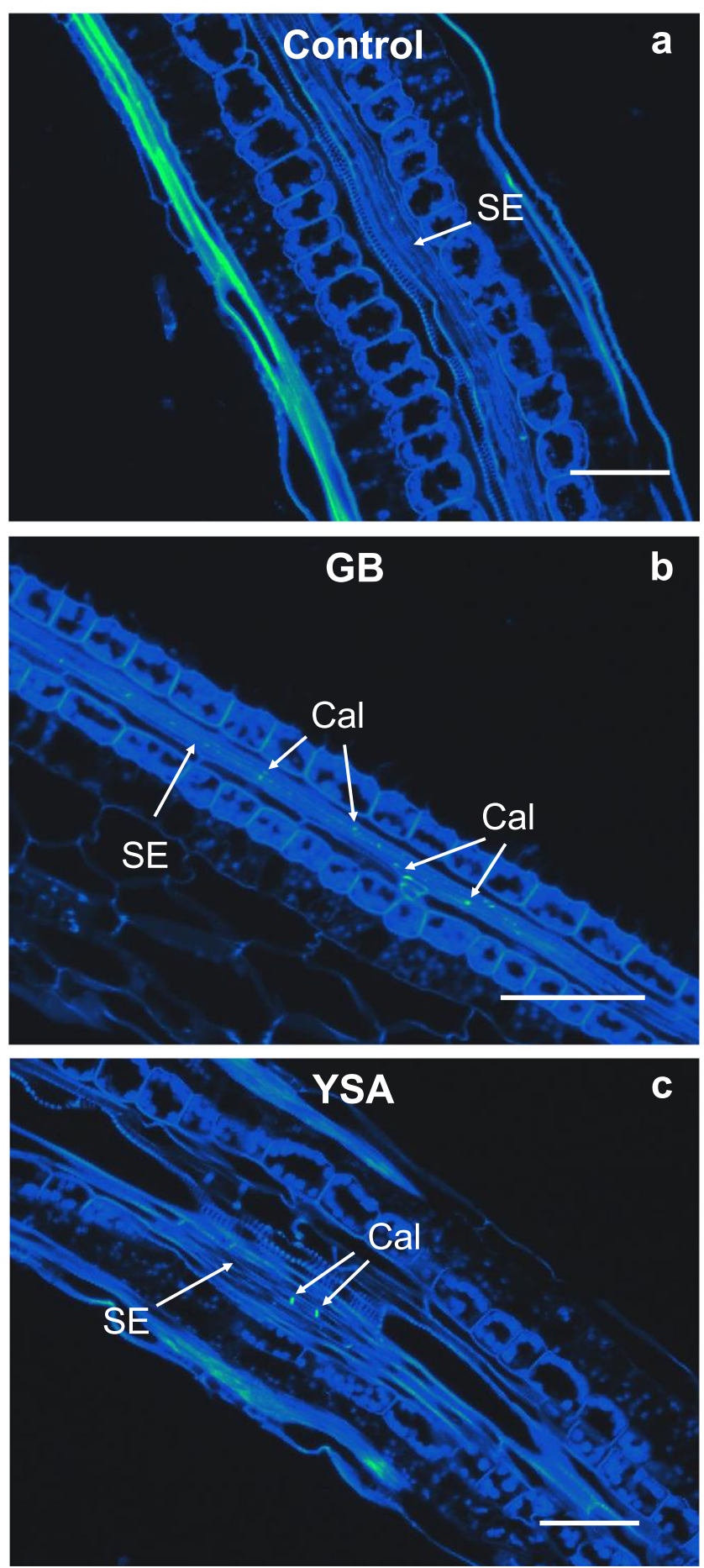

Fig. 4 Fluorescence micrographs of longitudinal leaf sections for Kanlow. a Control, b greenbug, and $\mathbf{c}$ yellow sugarcane aphid. Induced callose deposition (arrows) on the sieve plates

deposition may be an important part of Arabidopsis' induced defenses to whitefly feeding [23].

Despite multiple attempts aimed at elucidating the role of callose in switchgrass resistance, it remains unclear if sieve element occlusion via callose deposition is an important component of aphid resistance, based on our results. Generally, significant callose deposits in switchgrass leaves were not observed, regardless of treatment, using histochemical studies. Although there appeared to be an increase in callose deposits on Kanlow plants after 3 days of greenbug infestation; however, more work is needed here to further clarify this response.

In response to greenbug feeding, none of the callose synthase genes evaluated were significantly upregulated. However, three $\beta$-1,3-glucosidase genes were upregulated in Summer while two were upregulated in $\mathrm{K} \times \mathrm{S}$ in response to greenbugs. One possible explanation for this is that greenbugs could be inducing these glucanases to circumvent sieve element occlusion and create a more suitable feeding environment. For example, Du et al. [20] found that three callose synthase genes (GSL1, GSL5, and GSL10) in rice were upregulated by brown planthopper feeding in both resistant and susceptible plants. However, two glucanases (GNS5 and GNS9) were downregulated on the resistant transgenic plants, suggesting that the reduction in the glucan hydrolyzing enzyme on resistant plants prevented callose from decomposing and leading to sieve element occlusion [20]. Similarly, Hao et al. [22] reported an upregulation of glucanases in the brown planthopper-susceptible rice plants, which may be responsible for unplugging of the sieve tubes, which otherwise remain plugged on resistant plants.

Conversely, Saheed et al. [45] reported that callose deposition appeared to be regulated at the protein level, rather than at the transcriptional level, in barley infested by cereal aphids. Saheed et al. [45] documented that none of the putative barley GSL sequences were regulated transcriptionally upon aphid attack, despite abundant callose deposition. Rather, it is possible that callose synthesis could also be activated by changes in the intracellular distribution of a glucoside activator as a regulatory mechanism $[45,46]$. Moreover, Botha, Matsiliza [47] as well as van der Westhuizen et al. [48] have reported significant increases in glucanases on resistant plants following aphid feeding, suggesting that regulation of callose metabolism to prevent phloem transport cessation could be causally linked to resistance in some systems.

Intuitively, limiting phloem access would appear to be a particularly effective resistance strategy, since limiting the nutrient uptake by the aphids would not only preserve valuable resources in the host plant, but also negatively affect aphid demographics. However, although the EPG data pointed to phloem-based resistance in Kanlow plants, direct visualization of callose and qPCR of genes nominally associated with callose metabolism only provided equivocal supporting evidence. These data might indicate alternate sources of resistance in Kanlow, especially to greenbugs and limited resistance to the yellow sugarcane aphid in any of the tetraploid switchgrasses evaluated.

To our knowledge, this work provides the first detailed documentation of yellow sugarcane aphid feeding behavior. Previous work has documented a marked difference in 
Fig. 5 Transcript abundance of callose-related genes in aphidinfested plants. Gene expression was detected by RT-qPCR in a greenbug-infested and $\mathbf{b}$ yellow sugarcane aphid-infested Summer, $\mathrm{K} \times \mathrm{S}$, and Kanlow switchgrass. Expression of the indicated genes was compared to gene expression in uninfested control plants. A fold change $>1$ represents higher transcript abundance in infested plants. Mean \pm SEM is shown. Statistical significance at $P<0.05$ is indicated by an asterisk

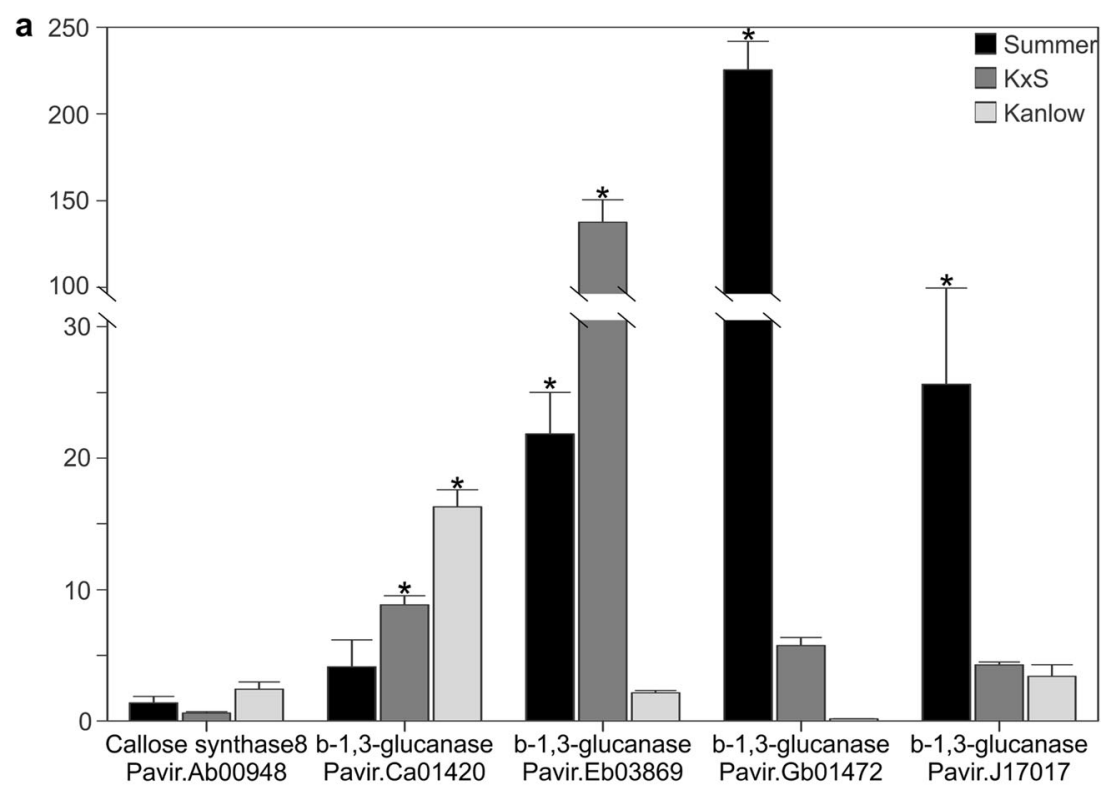

b

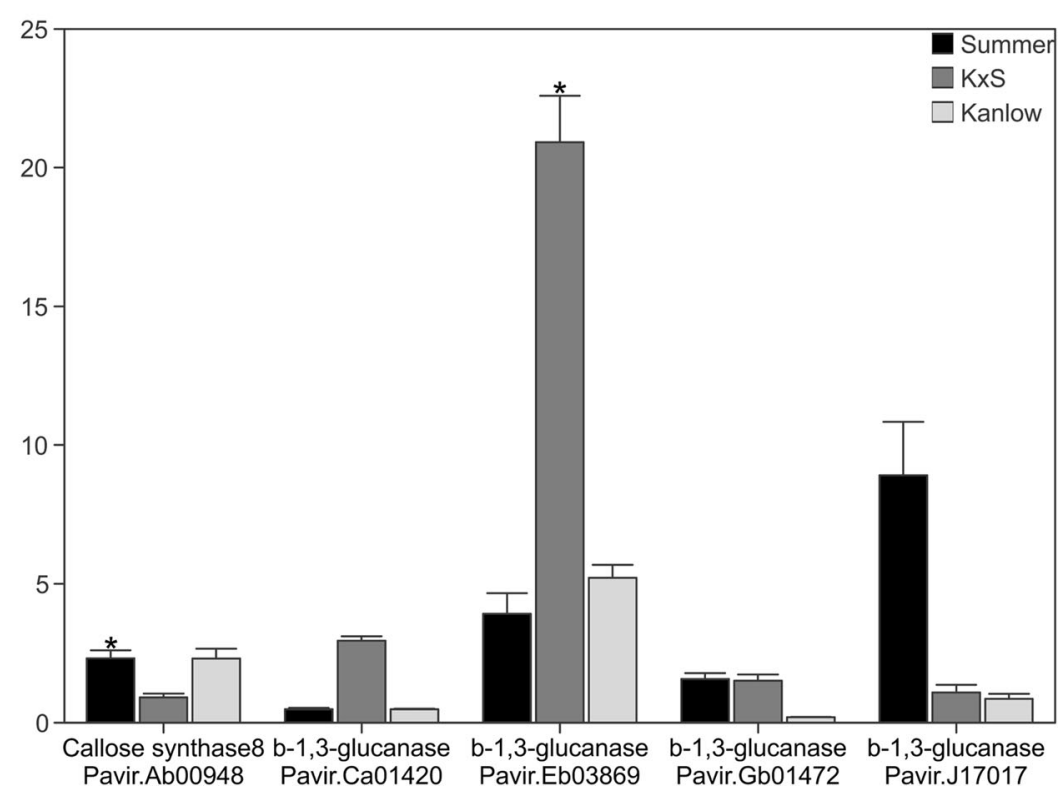

greenbug feeding behavior on resistant and susceptible V1 switchgrasses. Here, it was possible to show a similar effect of Kanlow on greenbug feeding behavior at the V3 developmental stage as well. However, few differences were identified for yellow sugarcane aphid feeding behavior on resistant and susceptible switchgrass at both V1 and V3 developmental stages. Crucially, this suggests that multiple mechanisms of resistance may be present in Kanlow to cereal aphids, which could in turn provide more durable resistance to aphids.

Acknowledgements We thank Katherine Keller for laboratory help. Mention of commercial products and organizations in this manuscript is solely to provide specific information. It does not constitute endorsement by USDA-ARS over other products and organizations not mentioned.
Funding Information This work was supported in part by grants from USDA-NIFA, Grant Number 2011-67009-30096, and by the USDAARS CRIS projects 3042-21000-030-00D. The U.S. Department of Agriculture, Agricultural Research Service, is an equal-opportunity/affirmative-action employer, and all agency services are available without discrimination.

\section{References}

1. Vogel KP (2004) Switchgrass. In: Moser LE, Sollenberger L, Burson B (eds) Warm-season (C4) grasses. ASA-CSSA-SSSA Monograph No. 45. ASA-CSSA-SSSA, Madison, pp 561-588. https://doi.org/10.1016/j.asj.2004.08.007

2. Mitchell R, Vogel KP, Sarath G (2008) Managing and enhancing switchgrass as a bioenergy feedstock. Biofuels Bioprod Bioref Biofpr 2(6):530-539. https://doi.org/10.1002/Bbb.106 
3. Mitchell R, Schmer M (2012) Switchgrass harvest and management. In: Monti A (ed) Switchgrass. Springer-Verlag, London, pp 113-127. https://doi.org/10.1007/978-1-4471-2903-5

4. Casler MD (2012) Switchgrass breeding, genetics and genomics. In: Monti A (ed) Switchgrass, Green Energy and Technology. Springer-Verlag, London, pp 29-53

5. Sanderson MA, Adler PR, Boateng AA, Casler MD, Sarath G (2006) Switchgrass as a biofuels feedstock in the USA. Can J Plant Sci 86(5):1315-1325

6. Sarath G, Mitchell RB, Sattler SE, Funnell D, Pedersen JF, Graybosch RA, Vogel KP (2008) Opportunities and roadblocks in utilizing forages and small grains for liquid fuels. J Ind Microbiol Biotechnol 35(5):343-354. https://doi.org/10.1007/s10295-0070296-3

7. Koch KG, Fithian R, Heng-Moss TM, Bradshaw JD, Sarath G, Spilker C (2014) Evaluation of tetraploid switchgrass (Poales: Poaceae) populations for host suitability and differential resistance to four cereal aphids. J Econ Entomol 107(1):424-431. https://doi. org/10.1603/EC13315

8. Prasifka JR, Buhay JE, Sappington TW, Heaton EA, Bradshaw JD, Gray ME (2011) Stem-boring caterpillars of switchgrass in the Midwestern United States. Ann Entomol Soc Am 104(3):507-514

9. Burd JD, Prasifka JR, Bradshaw JD (2012) Establishment and host effects of cereal aphids on switchgrass (Panicum virgatum L.) cultivars. Southwest Entomol 37(2):115-122. https://doi.org/10.3958/ 059.037.0203

10. Prasifka JR, Bradshaw JD, Boe AA, Lee D, Adamski D, Gray ME (2010) Symptoms, distribution and abundance of the stem-boring caterpillar, Blastobasis repartella (Dietz), in switchgrass. Bioenerg Res 3(3):238-242. https://doi.org/10.1007/s12155-009-9064-8

11. Donze-Reiner T, Palmer NA, Scully ED, Prochaska TJ, Koch KG, Heng-Moss T, Bradshaw JD, Twigg P, Amundsen K, Sattler SE, Sarath G (2017) Transcriptional analysis of defense mechanisms in upland tetraploid switchgrass to greenbugs. BMC Plant Biol 17(1): 46. https://doi.org/10.1186/s12870-017-0998-2

12. Smith CM (2005) Plant resistance to arthropods: molecular and conventional approaches. Springer, Dordrecht, Netherlands

13. Smith CM, Boyko EV (2007) The molecular bases of plant resistance and defense responses to aphid feeding: current status. Entomol Exp Appl 122(1):1-16. https://doi.org/10.1111/j.15707458.2006.00503.x

14. Koch KG, Bradshaw JD, Heng-Moss TM, Sarath G (2014) Categories of resistance to greenbug and yellow sugarcane aphid (Hemiptera: Aphididae) in three tetraploid switchgrass populations. Bioenerg Res 7(3):909-918. https://doi.org/10.1007/s12155-0149420-1

15. Koch KG, Palmer N, Stamm M, Bradshaw JD, Blankenship E, Baird LM, Sarath G, Heng-Moss TM (2015) Characterization of greenbug feeding behavior and aphid (Hemiptera: Aphididae) host preference in relation to resistant and susceptible tetraploid switchgrass populations. Bioenerg Res 8(1):165-174. https://doi.org/10. 1007/s12155-014-9510-0

16. Tjallingii WF (2006) Salivary secretions by aphids interacting with proteins of phloem wound responses. J Exp Bot 57(4):739-745. https://doi.org/10.1093/jxb/erj088

17. van Helden M, Tjallingii WF (2000) Experimental design and analysis in EPG experiments with emphasis on plant resistance research. In: Walker GP, Backus EA (eds) Principles and applications of electronic monitoring and other techniques in the study of homopteran feeding behavior. Thomas Say Publications in Entomology, Entomological Society of America, Lanham, pp 144-171

18. Jiang YX, Nombela G, Muniz M (2001) Analysis by DC-EPG of the resistance to Bemisia tabaci on an Mi-tomato line. Entomol Exp Appl 99(3):295-302. https://doi.org/10.1046/j.1570-7458.2001. 00828.x
19. Crompton DS, Ode PJ (2010) Feeding behavior analysis of the soybean aphid (Hemiptera: Aphididae) on resistant soybean 'Dowling'. J Econ Entomol 103(3):648-653. https://doi.org/10. 1603/Ec09370

20. Du B, Zhang WL, Liu BF, Hu J, Wei Z, Shi ZY, He RF, Zhu LL, Chen RZ, Han B, He GC (2009) Identification and characterization of Bph14, a gene conferring resistance to brown planthopper in rice. Proc Natl Acad Sci U S A 106(52):22163-22168. https://doi.org/ 10.1073/pnas.0912139106

21. Betsiashvili M, Ahern KR, Jander G (2015) Additive effects of two quantitative trait loci that confer Rhopalosiphum maidis (corn leaf aphid) resistance in maize inbred line Mo17. J Exp Bot 66(2):571578. https://doi.org/10.1093/Jxb/Eru379

22. Hao PY, Liu CX, Wang YY, Chen RZ, Tang M, Du B, Zhu LL, He G (2008) Herbivore-induced callose deposition on the sieve plates of rice: an important mechanism for host resistance. Plant Physiol 146(4):1810-1820. https://doi.org/10.1104/pp.107.111484

23. Kempema LA, Cui XP, Holzer FM, Walling LL (2007) Arabidopsis transcriptome changes in response to phloem-feeding silverleaf whitefly nymphs. Similarities and distinctions in responses to aphids. Plant Physiol 143(2):849-865. https://doi.org/10.1104/pp. 106.090662

24. Moore KJ, Moser LE, Vogel KP, Waller SS, Johnson BE, Pedersen JF (1991) Describing and quantifying growth stages of perennial forage grasses. Agron J 83(6):1073-1077. https://doi.org/10.2134/ agronj1991.00021962008300060027x

25. Jaouannet M, Rodriguez PA, Thorpe P, Lenoir CJG, MacLeod R, Escudero-Martinez C, Bos JIB (2014) Plant immunity in plantaphid interactions. Front Plant Sci 5:663. https://doi.org/10.3389/ fpls.2014.00663

26. Elzinga DA, De Vos M, Jander G (2014) Suppression of plant defenses by a Myzus persicae (green peach aphid) salivary effector protein. Mol Plant-Microbe Interact 27(7):747-756. https://doi.org/ 10.1094/MPMI-01-14-0018-R

27. Annan IB, Tingey WM, Schaefers GA, Tjallingii WF, Backus EA, Saxena KN (2000) Stylet penetration activities by Aphis craccivora (Homoptera : Aphididae) on plants and excised plant parts of resistant and susceptible cultivars of cowpea (Leguminosae). Ann Entomol Soc Am 93(1):133-140. https://doi.org/10.1603/00138746(2000)093[0133:Spabac]2.0.Co;2

28. Prado E, Tjallingii WF (1994) Aphid activities during sieve element punctures. Entomol Exp Appl 72(2):157-165. https://doi.org/10. 1111/j.1570-7458.1994.tb01813.x

29. Reese JC, Tjallingii WF, van Helden M, Prado E (2000) Waveform comparisons among AC and DC systems for electronic monitoring of aphid feeding behavior. In: Walker GP, Backus EA (eds) Principles and applications of electronic monitoring and other techniques in the study of homopteran feeding behavior. Thomas Say Publications in Entomology, Entomological Society of America, Lanham, MD. pp 70-101

30. Sarria E, Cid M, Garzo E, Fereres A (2009) Excel workbook for automatic parameter calculation of EPG data. Comput Electron Agric 67(1-2):35-42. https://doi.org/10.1016/j.compag.2009.02.006

31. SAS Institute (2008) PROC user's manual, 9.2 edn. SAS Institute, Cary, NC

32. Shapiro SS, Francia RS (1972) An approximate analysis of variance test for normality. J Am Stat Assoc 67(337):215. https://doi.org/10. 2307/2284728

33. Palmer NA, Donze-Reiner T, Horvath D, Heng-Moss T, Waters B, Tobias C, Sarath G (2015) Switchgrass (Panicum virgatum L) flag leaf transcriptomes reveal molecular signatures of leaf development, senescence, and mineral dynamics. Funct Integr Genomics 15(1):1-16. https://doi.org/10.1007/s10142-014-0393-0

34. Chomczynski P, Sacchi N (1987) Single-step method of RNA isolation by acid guanidinium thiocyanate phenol chloroform 
extraction. Anal Biochem 162(1):156-159. https://doi.org/10.1016/ 0003-2697(87)90021-2

35. Schmittgen TD, Livak KJ (2008) Analyzing real-time PCR data by the comparative C(T) method. Nat Protoc 3(6):1101-1108. https:// doi.org/10.1038/nprot.2008.73

36. Smith CM, Chuang WP (2014) Plant resistance to aphid feeding: behavioral, physiological, genetic and molecular cues regulate aphid host selection and feeding. Pest Manag Sci 70(4):528-540. https://doi.org/10.1002/ps.3689

37. Zhai Y, Li P, Mei Y, Chen MY, Chen XC, Xu H, Zhou X, Dong HS, Zhang CL, Jiang WH (2017) Three MYB genes co-regulate the phloem-based defence against English grain aphid in wheat. $\mathrm{J}$ Exp Bot 68(15):4153-4169. https://doi.org/10.1093/jxb/erx204

38. Mehrabi S, Ahman I, Jonsson LMV (2016) The constitutive expression and induction of three beta-1,3-glucanases by bird cherry-oat aphid in relation to aphid resistance in 15 barley breeding lines. Arthropod Plant Interact 10(2):101-111. https://doi.org/10.1007/ s11829-016-9415-2

39. Pettersson J, Tjallingii WF, Hardie J (2007) Host-plant selection and feeding. In: van Emden HF, Harrington R (eds) Aphids as crop pests. CABI, Cambridge, MA, pp 87-113

40. Argandona VH, Corcuera LJ, Niemeyer HM, Campbell BC (1983) Toxicity and feeding deterrency of hydroxamic acids from Gramineae in synthetic diets against the greenbug, SchizaphisGraminum. Entomol Exp Appl 34(2):134-138. https://doi.org/10. 1111/j.1570-7458.1983.tb03307.x

41. Lattanzio V, Arpaia S, Cardinali A, Di Venere D, Linsalata V (2000) Role of endogenous flavonoids in resistance mechanism of Vigna to aphids. J Agric Food Chem 48(11):5316-5320. https://doi.org/10. 1021/jf000229y

42. Corcuera LJ (1990) Plant-chemicals and resistance of cereals to aphids. Ambio 19(8):365-367

43. Gierl A, Frey M (2001) Evolution of benzoxazinone biosynthesis and indole production in maize. Planta 213(4):493-498. https://doi. org/10.1007/s004250100594

44. Lin CH, Lerch RN, Garrett HE, George MF (2008) Bioremediation of atrazine-contaminated soil by forage grasses: transformation, uptake, and detoxification. J Environ Qual 37(1):196-206. https://doi. org/10.2134/jeq2006.0503

45. Saheed SA, Cierlik I, Larsson KAE, Delp G, Bradley G, Jonsson LMV, Botha CEJ (2009) Stronger induction of callose deposition in barley by Russian wheat aphid than bird cherry-oat aphid is not associated with differences in callose synthase or beta-1,3glucanase transcript abundance. Physiol Plant 135(2):150-161. https://doi.org/10.1111/j.1399-3054.2008.01180.x

46. Ohana P, Benziman M, Delmer DP (1993) Stimulation of callose synthesis invivo correlates with changes in intracellular-distribution of the callose synthase activator beta-furfuryl-beta-glucoside. Plant Physiol 101(1):187-191. https://doi.org/10.1104/pp.101.1.187

47. Botha CEJ, Matsiliza B (2004) Reduction in transport in wheat (Triticum aestivum) is caused by sustained phloem feeding by the Russian wheat aphid (Diuraphis noxia). S Afr J Bot 70(2):249-254. https://doi.org/10.1016/S0254-6299(15)30242-8

48. van der Westhuizen AJ, Qian XM, Wilding M, Botha AM (2002) Purification and immunocytochemical localization of a wheat beta1,3-glucanase induced by Russian wheat aphid infestation. S Afr J Sci 98(3-4):197-202 


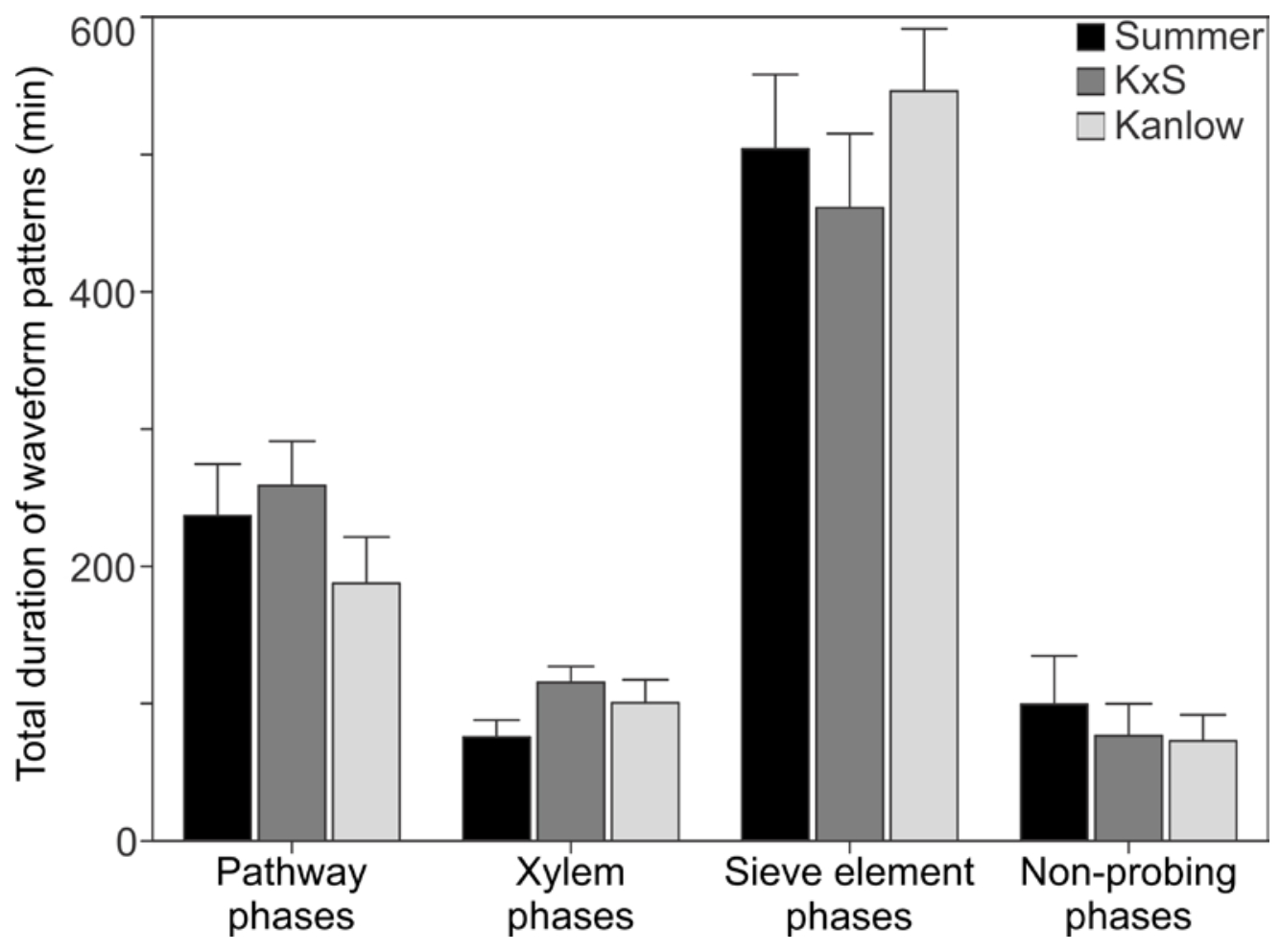

Resource 1. Comparison of EPG parameters (mean \pm SEM) for duration of pathway, xylem, phloem and non-probing phases for $15 \mathrm{hr}$ of yellow sugarcane aphid feeding on three switchgrass populations (V1 stage). No significant pairwise differences were detected between the means of duration variables of Summer, KxS and Kanlow ( $P>0.05)$, LSD test. 
Online Resource 2. Comparison of EPG parameters (mean \pm SEM) for stylet activities for 15 hr of yellow sugarcane aphid feeding on switchgrass populations (V1 stage). No significant pairwise differences were detected between the means of probing variables of Summer, KxS and Kanlow (P>0.05), LSD test.

\begin{tabular}{|c|c|c|c|}
\hline \multirow[b]{2}{*}{ Feeding Variable } & \multicolumn{3}{|c|}{ Mean \pm SEM } \\
\hline & Summer & KxS & Kanlow \\
\hline potential drops & $90.4 \pm 20.0$ & $72.7 \pm 10.4$ & $90.8 \pm 24.3$ \\
\hline pathway phases & $21.3 \pm 3.1$ & $19.7 \pm 1.5$ & $17.7 \pm 2.6$ \\
\hline xylem phases & $4.8 \pm 0.7$ & $3.9 \pm 0.6$ & $3.1 \pm 0.5$ \\
\hline SEP $^{1}$ events & $7.5 \pm 1.0$ & $7.7 \pm 0.7$ & $7.5 \pm 1.1$ \\
\hline Sustained SEP ${ }^{2}$ events & $4.9 \pm 0.7$ & $5.6 \pm 0.6$ & $5.8 \pm 0.7$ \\
\hline $\mathrm{NP}^{3}$ events & $9.6 \pm 2.2$ & $8.4 \pm 1.1$ & $7.4 \pm 2.1$ \\
\hline $\begin{array}{l}\text { Potential phloem ingestion index } \\
\text { (PPII) }\end{array}$ & $60.7 \pm 5.1$ & $66.3 \pm 3.7$ & $67.4 \pm 5.7$ \\
\hline $\begin{array}{l}\% \text { of aphids showing sustained SEP } \\
(\mathrm{E}>10 \mathrm{~min} .)\end{array}$ & $95(19 / 20)$ & $100(20 / 20)$ & $95(19 / 20)$ \\
\hline
\end{tabular}

\footnotetext{
${ }^{1}$ Sieve element phase

${ }^{2}$ Sustained sieve element phase $(E>10 \mathrm{~min})$

${ }^{3}$ Non-probing
} 
Online Resource 3. Comparison of EPG parameters (mean \pm SEM) for time and duration of pattern segments for $15 \mathrm{hr}$ of yellow sugarcane aphid feeding on switchgrass populations (V3 stage). No significant pairwise differences were detected between the means of probing variables of Summer, KxS and Kanlow (P > 0.05), LSD test.

\begin{tabular}{llcc}
\hline & \multicolumn{3}{c}{ Mean \pm SEM } \\
\cline { 2 - 4 } Feeding Variable & \multicolumn{1}{c}{ Summer } & KxS & Kanlow \\
\hline Time to $1^{\text {st }}$ probe & & \multicolumn{3}{c}{ a } & $1.1 \pm 0.6$ & $1.2 \pm 0.6$ \\
Time to $1^{\text {st }}$ SEP $^{1}$ & $1.2 \pm 0.5$ & $89.4 \pm 25.9$ & $96.5 \pm 19.5$ \\
Time to $1^{\text {st }}$ sustained SEP & & & $162.6 \pm 58.5$ \\
Mean duration of SEP & $278.8 \pm 103.3$ & $310.6 \pm 111.8$ & $156.2 \pm 41.7$ \\
Duration of $1^{\text {st }}$ SEP & $127.8 \pm 32.2$ & $92.8 \pm 16.3$ & $93.2 \pm 45.8$ \\
\hline
\end{tabular}

a Time and duration calculated in minutes

${ }^{1}$ Sieve element phase

${ }^{2}$ Sustained sieve element phase $(\mathrm{E}>10 \mathrm{~min})$ 
Online Resource 4. Comparison of EPG parameters (mean \pm SEM) for stylet activities for 15 hr of yellow sugarcane aphid feeding on switchgrass populations (V3 stage). No significant pairwise differences were detected between the means of probing variables of Summer, KxS and Kanlow (P>0.05), LSD test.

\begin{tabular}{|c|c|c|c|}
\hline \multirow[b]{2}{*}{ Feeding Variable } & \multicolumn{3}{|c|}{ Mean \pm SEM } \\
\hline & Summer & $\mathbf{K x S}$ & Kanlow \\
\hline potential drops & $119.0 \pm 26.2$ & $111.7 \pm 20.0$ & $71.7 \pm 14.3$ \\
\hline pathway phases & $22.7 \pm 4.2$ & $23.7 \pm 4.1$ & $17.1 \pm 2.9$ \\
\hline xylem phases & $4.4 \pm 0.8$ & $7.0 \pm 1.4$ & $4.8 \pm 1.0$ \\
\hline $\mathrm{SEP}^{1}$ events & $6.6 \pm 1.0$ & $7.0 \pm 0.9$ & $5.2 \pm 0.6$ \\
\hline Sustained SEP ${ }^{2}$ events & $3.4 \pm 0.6$ & $3.5 \pm 0.5$ & $3.5 \pm 0.4$ \\
\hline $\mathrm{NP}^{3}$ events & $12.2 \pm 3.4$ & $10.0 \pm 2.7$ & $7.4 \pm 1.9$ \\
\hline $\begin{array}{l}\text { Potential phloem ingestion index } \\
\text { (PPII) }\end{array}$ & $63.1 \pm 6.7$ & $56.1 \pm 6.2$ & $67.8 \pm 5.3$ \\
\hline $\begin{array}{l}\% \text { of aphids showing sustained SEP } \\
(\mathrm{E}>10 \mathrm{~min} .)\end{array}$ & $90(18 / 20)$ & $100(20 / 20)$ & $95(19 / 20)$ \\
\hline
\end{tabular}

${ }^{1}$ Sieve element phase

${ }^{2}$ Sustained sieve element phase $(E>10 \mathrm{~min})$

${ }^{3}$ Non-probing 
Online Resource 5. Gene description, gene ID, and gene fold change for callose related genes when comparing greenbug infested and uninfested switchgrass. A fold change $>1$ represents higher transcript abundance in greenbug infested plants. A fold change $<1$ indicates higher transcript abundance in uninfested control plants. A fold change equal to 1 indicates no difference between transcript abundance for either treatment $(\mathrm{P}<0.05)$.

\begin{tabular}{|c|c|c|c|c|c|c|c|}
\hline \multirow[b]{2}{*}{ Transcript } & \multirow[b]{2}{*}{ Gene ID } & \multicolumn{2}{|c|}{ Summer } & \multicolumn{2}{|c|}{$\mathbf{K x S}$} & \multicolumn{2}{|c|}{ Kanlow } \\
\hline & & $\begin{array}{l}\text { Fold } \\
\text { change }\end{array}$ & $P$-value ${ }^{\mathrm{a}}$ & $\begin{array}{l}\text { Fold } \\
\text { change }\end{array}$ & $P$-value $e^{\mathrm{a}}$ & $\begin{array}{l}\text { Fold } \\
\text { change }\end{array}$ & $P$-value \\
\hline$\beta$-1,3-glucanase & Pavir.Bb02930 & 14.59 & 0.0799 & 6.83 & 0.1693 & 1.28 & 0.8775 \\
\hline $\begin{array}{l}\beta-1,3 \text {-glucan synthase } \\
\text { complex }\end{array}$ & Pavir.Db00045 & 8.64 & 0.3334 & 1.02 & 0.9436 & 2.03 & 0.4253 \\
\hline$\beta$-1,3-glucanase & Pavir.Ga01393 & 0.94 & 0.9321 & 1.14 & 0.6508 & 0.89 & 0.6885 \\
\hline Callose synthase 3 & Pavir.Ia04498 & 2.25 & 0.3627 & 0.50 & 0.2203 & 0.40 & 0.1054 \\
\hline
\end{tabular}

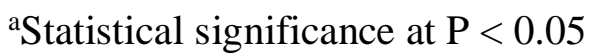


Online Resource 6. Gene description, gene ID, and gene fold change for callose related genes when comparing yellow sugarcane aphid infested and uninfested switchgrass. A fold change $>1$ represents higher transcript abundance in infested plants. A fold change $<1$ indicates higher transcript abundance in uninfested control plants. A fold change equal to 1 indicates no difference between transcript abundance for either treatment $(\mathrm{P}<0.05)$.

\begin{tabular}{|c|c|c|c|c|c|c|c|}
\hline \multirow[b]{2}{*}{ Transcript } & \multirow[b]{2}{*}{ Gene ID } & \multicolumn{2}{|c|}{ Summer } & \multicolumn{2}{|c|}{$\mathbf{K x S}$} & \multicolumn{2}{|c|}{ Kanlow } \\
\hline & & $\begin{array}{l}\text { Fold } \\
\text { change }\end{array}$ & $P$-value $e^{\mathrm{a}}$ & $\begin{array}{l}\text { Fold } \\
\text { change }\end{array}$ & $P$-value ${ }^{\mathrm{a}}$ & $\begin{array}{l}\text { Fold } \\
\text { change }\end{array}$ & P-value \\
\hline$\beta$-1,3-glucosidase & Pavir.Bb02930 & 2.75 & 0.6345 & 4.21 & 0.9881 & 1.57 & 0.6679 \\
\hline $\begin{array}{l}\beta \text {-1,3-glucan synthase } \\
\text { complex }\end{array}$ & Pavir.Db00045 & 5.10 & 0.0606 & 1.76 & 0.7953 & 4.13 & 0.1206 \\
\hline$\beta$-1,3-glucosidase & Pavir.Ga01393 & 1.30 & 0.8752 & 1.44 & 0.9594 & 1.15 & 0.8081 \\
\hline Callose synthase 3 & Pavir.Ia04498 & 2.74 & 0.1858 & 0.49 & 0.1841 & 0.80 & 0.8377 \\
\hline
\end{tabular}

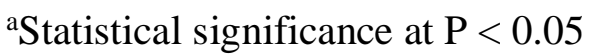

